\title{
Insects of forensic importance from Rio Grande do Sul state in southern Brazil
}

\author{
Alex Sandro Barros de Souza ${ }^{1}$, Frederico Dutra Kirst ${ }^{1} \&$ Rodrigo Ferreira Krüger ${ }^{2}$
}

${ }^{1}$ Coordenação de Pesquisas em Entomologia - Instituto Nacional de Pesquisas da Amazônia/INPA - Campus II, Caixa Postal 478, 69011-970 Manaus-AM; +55 92 3643-3201. alexsouza@inpa.gov.br; fdkirst@inpa.gov.br

${ }^{2}$ Campus Rio Paranaíba Universidade Federal de Viçosa, Rodovia BR 354 - km 310, 38810-000 Rio Paranaíba-MG , +55 3138993136. rfkruger@insecta.ufv.br

\begin{abstract}
Insects of forensic importance from Rio Grande do Sul state in southern Brazil. The experiment was conducted throughout the year 2005, at the Universidade Federal de Pelotas campus. The objectives of the study were to analyze the decomposition of rabbit (Oryctolagus cunniculus L.) with mean weight $2.67 \mathrm{Kg}$ carcass and describe the interaction of insects acting on it, as well as the insect's potential use in legal medicine. We collected 5.239 insect specimens; 1.827 of them were obtained from larvae collected from carcasses and reared. The specimens were identified and 20 species were of forensic importance. The species Lucilia eximia (Wiedemann, 1819) and Chrysomya albiceps (Wiedemann, 1819) (Diptera, Calliphoridae) were better indicators of post-mortem interval (PMI) because they occurred in all seasons and were the first to reach the carcass. Hemilucilia semidiaphana (Rondani, 1850), H. segmentaria (Fabricius, 1805) (Diptera, Calliphoridae), Muscina stabulans (Fallén, 1817) and Synthesiomyia nudiseta (Wulp, 1883) (Diptera, Muscidae) can disclose death time because they occur only in certain months of the year. Oxyletrum discicolle (Brullé, 1840) (Coleoptera, Silphidae) and Dermestes maculates De Geer, 1774 (Coleoptera, Desmestidae) were found in advanced stages of decomposition.
\end{abstract}

KEYWORDS. Carrion fauna; Coleoptera; Diptera; forensic entomology; IPM.

RESUMO. Insetos de importância forense do Rio Grande do Sul, sul do Brasil. Durante todas as estações do ano de 2005 foi conduzido um experimento em uma área do campus da Universidade Federal de Pelotas. O objetivo do estudo foi analisar a decomposição de carcaças de coelho (Oryctolagus cunniculus L.) pesando 2,67 Kg em média e descrever como os insetos atuam na decomposição e seu possível uso na medicina-legal. Foram coletados 5.239 espécimes; 1.827 foram obtidos a partir da criação de imaturos coletados na carcaça. Foram identificadas 20 espécies com importância forense. As espécies mais propícias para serem usadas com indicadoras de intervalo post-mortem (IPM) são Lucilia eximia (Wiedemann, 1819) e Chrysomya albiceps (Wiedemann, 1819) (Diptera, Calliphoridae) por terem sido encontradas em todas as estações de coleta e por serem uma das primeiras espécies a chegar à carcaça. Hemilucilia semidiaphana (Rondani, 1850), H. segmentaria (Fabricius, 1805) (Diptera, Calliphoridae), Muscina stabulans (Fallén, 1817) e Synthesiomyia nudiseta (Wulp, 1883) (Diptera, Muscidae) são espécies que podem indicar época da morte, pois ocorrem em meses específicos do ano. Oxyletrum discicolle (Brullé, 1840) (Coleoptera, Silphidae) e Dermestes maculatus De Geer, 1774 (Coleoptera, Desmestidae) são encontrados em estágios avançados de decomposição.

PALAVRAS-CHAVE. Diptera; Coleoptera; decomposição; entomologia forense; IPM.

Decomposition is responsible for returning the organic matter of dead plant and animals to the ecosystem. Decomposition is first carried out by fungi and bacteria, and then by large variety of arthropods (Weigelt 1989). The process consists of the metabolic transformation of organic matter into simple organic and inorganic compounds, with energy release. The degradation process is continuous, but its division into stages makes their study easier; the number and duration of stages are highly dependent on climatic and seasonal variations (Keh 1985; Richards \& Goff 1997). The importance of the decomposition process has reached beyond its role in nutrient transformation, as it contributes for the establishment of associated communities (Moura 2004).

Studies of fauna associated with cadavers are the most important application of entomology to legal medicine, whereby stored data can be used as forensic indicators. Some of the species collected in these studies not only visit the carcass, but also use it as a resource during their immature development stages (Keh 1985). The identification of larvae development period makes possible the determination of the post-mortem interval (PMI) (Catts \& Haskell 1991).

Firstly, the determination of PMI depends on the physical conditions of the cadaver; in late-decomposition cases, on the study of bones and associated fauna (Oliveira-Costa 2008). For greater reliability, such studies are conducted by an entomologist and other experts, such as a legal physician and a forensic pathologist (Catts \& Haskell 1991). These studies provide an initial data basis on species adapted to human biocenose and their oviposition preferences, indicating the species to be used for forensic investigations. In Brazil, most studies of this kind have been conducted in Rio Claro (Gomes \& Von-Zuben 2004), Campinas (Monteiro-Filho \& Peneireiro 1987; Sousa \& Linhares 1997; Carvalho et al. 2001; Carvalho \& Linhares 2001), Rio de Janeiro (Salviano et al. 1996; Oliveira- 
Costa \& Mello-Pattiu 2004), and Curitiba (Moura et al. 1997, Mise et al. 2007).

In our paper, we discuss two central issues in forensic entomology. First, the truly necrophagous species that can be used as forensic indicators in the Pelotas region, southern Brazil. Second, we discuss the seasonal insect behaviours. Both approaches will contribute for the development of forensic entomology in the extreme South of Brazil, as a data basis for further medico-criminal investigations in the region.

\section{MATERIALAND METHODS}

Site description. The research was conducted on the campus of the Universidade Federal de Pelotas ( $31^{\circ} 48^{\prime} 58^{\prime \prime}$ S; $52^{\circ} 25^{\prime} 55^{\prime}$ 'W), Capão do Leão, Rio Grande do Sul (RS), southern coastal plains, bioma Campo Sulinos, Brazil. The climate is Cfa (Köppen classification), with annual mean temperature and rainfall $18.2^{\circ} \mathrm{C}$ and $1283 \mathrm{~mm}$, respectively.

Experimental proceeding. Metal cages $(50 \mathrm{~cm}$ x $40 \mathrm{~cm})$ were used for the exclusion of necrophagous vertebrates. Each cage was placed at a depth of $10 \mathrm{~cm}$, for carcass contact with the soil. At each collection site, a small area was cleaned for better visualization and installation of the cage, following the pattern described in Monteiro-Filho and Peneireiro (1987).

Four female rabbit carcasses, with mean weight $2.67 \pm 0.71$ $\mathrm{Kg}$ were used. All animals were mechanically killed by cervical displacement; chemical substances that could affect the decomposition process were not used (Micozzi 1986).

Specimens Collection. The carcasses were observed daily, between 11 am and $2 \mathrm{pm}$, with a minimum observation time of one hour per sample. The following data on carcass condition were collected: decomposition stage, presence of larvae, and decomposed organs, following the stage nomenclature proposed by Rodriguez \& Bass (1983).

The collections were conducted with minimum impact on the fauna, particularly on the immature specimens. The actively flying insects were collected with a modified entomological net. Insects not captured for the trap and immature specimens in larvae stage were collected directly on the carcass and in the cages, with tweezers. All adult insects were killed with ethyl acetate and preserved dry by entomological mounting or in alcohol $70 \%$.

The larvae were placed into containers with ground beef, and placed in larger vials containing moist soil brought from the collection site, for further pupariation of the reared individuals. These vials were properly labelled with the date and larva instars', and covered with tulle. The pots were placed at the Laboratory of Biology of Insects, Microbiology and Parasitology Departament, Universidade Federal de Pelotas. Temperature was not controlled until adult emergence due to seasonality.

Climatic data were provided by the Agriculture Climatological Station, Embrapa-Universidade Federal de Pelotas.

\section{RESULTS}

Environmental conditions. Maximum and minimum temperatures are in Figure 1, and means of relative humidity are 72,$78 ; 82,3 ; 89,5$ and $85,71 \%$ in spring, summer, autumn and winter, respectively.

The lowest mean for maximum temperature occurred in the winter. For the other seasons the temperature was approximately $27^{\circ} \mathrm{C}$ and a variation lower than $1^{\circ} \mathrm{C}$. The widest temperature range per day was observed in the summer (13$\left.31.6^{\circ} \mathrm{C}\right)$ and fall $\left(19-30.2^{\circ} \mathrm{C}\right)$.

Relative humidity means were stable in all seasons, approximately $86 \%$, except for the winter, when the lowest relative humidity mean was observed.

The duration of each experiment accomplished a change of temperature on each season (Fig. 2).

\section{Decomposition Stages.}

Fresh Stage. Carcass shape has no visible change. Only the body has a slight muscular rigidity that disappears in a few hours, except in the winter, when rigidity lasted approximately 48 hours. Small lesions on the nose and the external ear due to the action of Pheidole sp. and Camponotus rufipes Fabricius, 1775 (Hymenoptera, Formicidae) can also be seen.

Bloated Stage. The abdominal region swells due to bacterial action (Smith 1986). It is in the bloated stage that some ovipositions can be seen, particularly in the mouth and anus, which leads to an increase in the populations of Pheidole sp. and $C$. rufipes. These individuals start predating eggs and some first instar larvae. Other insects also begin to visit the animal, such as Deltochilum sp. (Coleoptera, Staphylinidade), Euspilotus "group" azureus sp. (Coleoptera, Histeridae), and Oxyletrum discicolle (Coleoptera, Silphidae).

Decaying Stage. The greater structural changes in the carcass and the intensification of insect action in the decomposition process can be observed. This stage has the greatest richness of species, which are attracted either by the exudates discharged by the body or by the large quantity of larvae developing in the carcass. Larvae of Peckia (Pattonella) resona (Lopes, 1935) (Diptera, Sarcophagidae) and other insects start to develop, such as Dermestes maculatus (Coleoptera, Dermestidae) Gastrisus sp. (Coleoptera, Staphylinidae), Necrobia rufipes (De Geer, 1775), and Necrobia ruficollis (Fabricius, 1775) (Coleoptera, Cleridae). Populations of Pheidole sp, C. rufipes and Euspilotus "group"azureus sp. also are maintained.

Adipocere-like Stage. This stage is characterized by hydrolysis of the carcass fatty tissue. The carcass loses its shape completely and becomes a mass of non-decomposed hair, fat, skin, and cartilage. Decomposition occurs firstly in the subepitelial fat, which becomes a mass containing parts of the digestive tract. The skin becomes rigid and protects the 

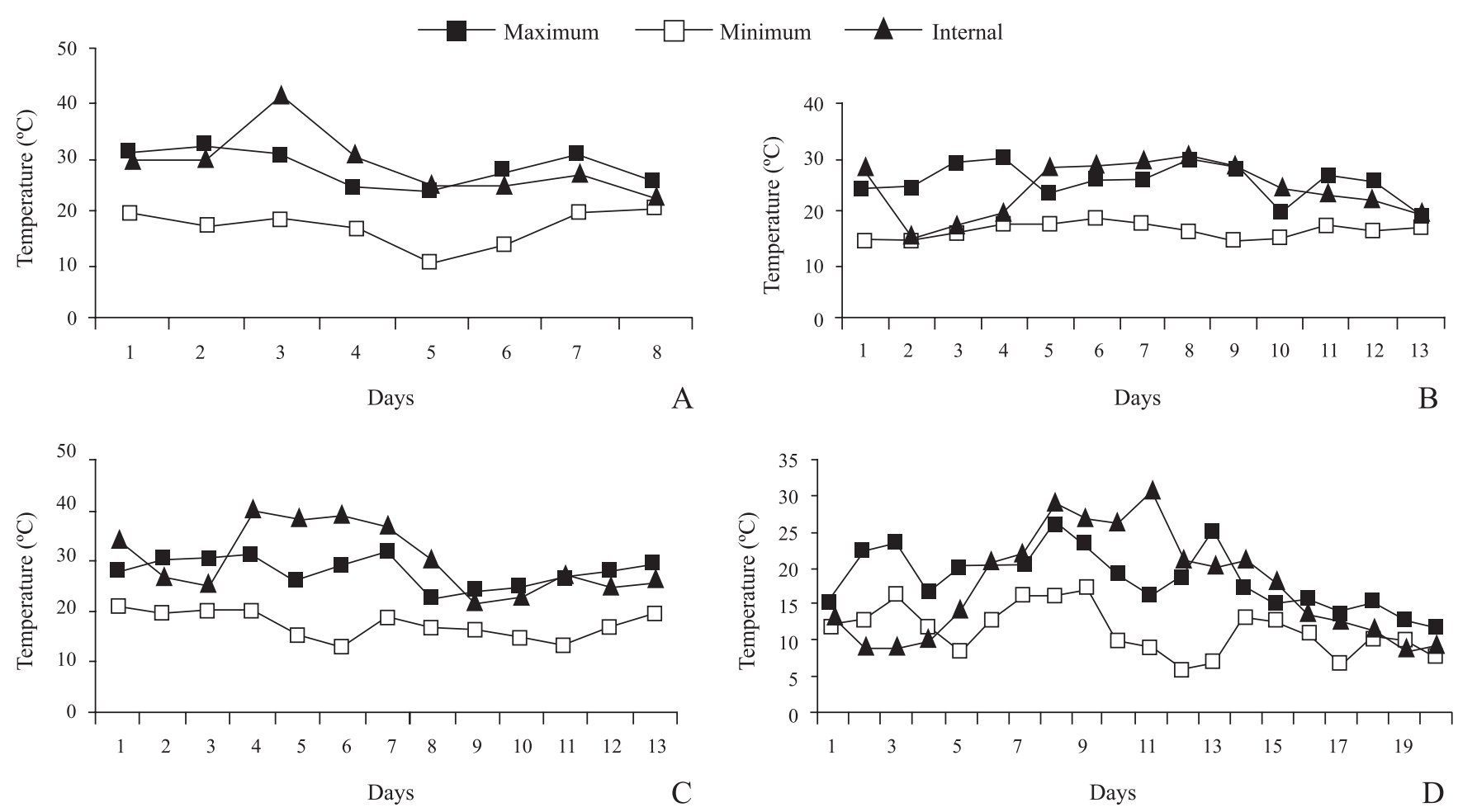

Fig. 1. Relation of maximum, minimum and internal temperature $\left({ }^{\circ} \mathrm{C}\right)$ in Spring (A), Summer (B), Autumn (C) and Winter (D).

larvae remaining in the carcass as well as the insects attached underneath the carcass, on the soil. No insect characterizes this stage, but Sarconesia chlorogaster (Wiedemann, 1830) (Diptera, Calliphoridae) and Muscina stabulans (Diptera, Muscidae) were present in winter.

Dry Stage. In contact with air, the carcass skin dries completely due to the incidence of sun rays. Also in this stage, the internal organs decompose completely. Decomposition starts to slow down, with a strong decline in the number of associated species. The skin portions exposed directly to sun rays become very hard and partially twisted. Diptera do not oviposit in this stage. We found final instar larvae of $D$. maculatus and Oxyletrum discicolle, as well as adults of Pheidole sp, C. rufipes, N. rufipes, and Gastrisus sp.

Insects of Forensic Importance. Of the 5.239 collected specimens, 1.827 were obtained from the larvae collected on the carcass and reared. All specimens were identified and 20 of them have medico-legal (Table I) either because they used the carcass as rearing site or played an important role in controlling populations in immature stages. Only Coleoptera $D$. maculatus and $O$. discicolle used the carcass as rearing sites for their immature; all others use it only for feeding the adults.

Three patterns were observed that species were indicators of post-mortem interval (PMI): I. Species found in all seasons, such as Lucilia eximia, Chrysomya albiceps, Gastrisus sp., Euspilotus "group"azureus sp., Pheidole sp., and
Camponotus rufipes; II. Species found in two seasons, such as Peckia (Pattonella) resona and Muscina stabulans in autumn and winter; III. Species found in one season, such as Hemilucilia semidiaphana and Sarconesia chlorogaster in winter and Hemilucilia segmentaria, Fannia pusio (Wiedemann, 1830) (Diptera, Fanniidae), and Synthesiomyia nudiseta in autumn.

Lucilia eximia and Chrysomya albiceps started visiting the carcass during the fresh stage. All other species started in the bloated stage, except in the winter, when Muscina stabulans appeared during the fresh stage. Among the Coleoptera species, only Euspilotus "group"azureus sp., Gastrisus sp. and $O$. discicolle started their visits during the bloated stage; all others were found from the decaying stage on. Pheidole sp. remained in the carcasses during all stages.

By observing reared species, we found that Calliphoridae is firstly seen in the carcass two to four days after the individual death. Only Hemilucilia semidiaphana was found six decomposition days, in winter. Larvae of L. eximia were found in the first days of carcass exposure, whereas larvae of $C$. albiceps were found mainly in the last decomposition stages. Among the Muscidae, larvae of M. stabulans were found two days after the animal death and the larvae of S. nudiseta were found three days after the anima death. Third-instar larvae of Peckia (Pattonella) resona were found approximately four days after death, in autumn and winter (Table II). The $O$. discicolle larvae were first seen nine days after death in autumn and after 10 in winter; D. maculatus were found after 12 days, in winter. 


\section{DISCUSSION}

The carcass decomposition period in our study differs from previous research results obtained in Brazil and other countries, probably because variation in carcass size and environmental conditions was important for determining process duration. In Curitiba, the decomposition period of rats weighing approximately 250g (Moura et al. 1997) was five times shorter than the period observed in our study, and approximately three days longer for pigs weighing $10 \mathrm{Kg}$ (Carvalho \& Linhares 2001). In India, the decomposition rate of rabbits weighing $1.2 \mathrm{~kg}$ was lower than the rate we observed (Bharti \& Singh 2003) The decomposition period for carcasses of rabbits reared in the desert was much longer, particularly in the last decomposition stages (Tantawi et al. 1996).

The findings above support the hypothesis that communities are affected by local and geographic variations Campobasso et al. (2001), although it is widely accepted that bodies decompose more slowly in forest areas (Carvalho \& Linhares 2001).

The necrophagous species collected in our study are very similar in genus to those collected by Carvalho \& Linhares (2001) in pigs, by Oliveira-Costa et al. (2001) in human corpses, and by Moura et al. (1997) in rats. Carvalho \& Linhares (2001) collected eight species of Calliphoridae; two of them were dominant, as also found by other authors such as OliveiraCosta et al. (2001), who collected seven species and three of them were dominant. In this kind of community, one or two dominant species are commonly found, which suggests that they should be considered as potential species for the determination of PMI (Goff et al. 1988).

In our study, L. eximia and C. albiceps did not prefer any season for visiting the carcass; they alternated their population peaks and presented an inverse relation. This situation can be

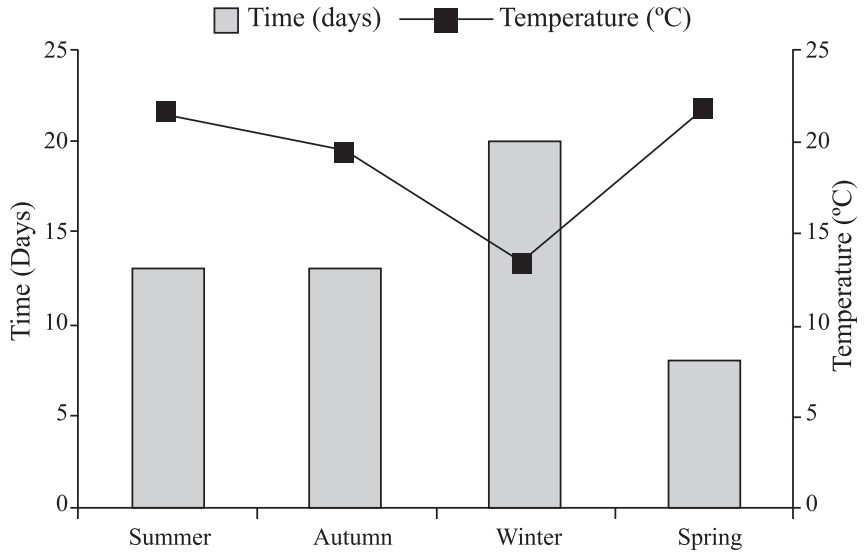

Fig. 2. Duration (days) of each experiment in relation to temperature $\left({ }^{\circ} \mathrm{C}\right)$ during the four seasons.

easily observed in the summer, when C. albiceps was collected in larger numbers and $L$. eximia was little abundant. This might be due to the predator role of $C$. albiceps (Denno \& Cothran 1975), thus explaining the asynchronic behavior of the two species, as they were constant in winter, due to the longer decomposition period that enhanced the species' coexistence (Moura 2004).

Hemilucilia semidiaphana and $H$. segmentaria also were collected in Curitiba (Moura et al. 1997) and Campinas (Carvalho \& Linhares 2001), the former collected in winter and the latter in autumn. In our studies, Hemilucilia semidiaphana and $H$. segmentaria were collected in the summer and spring. Sarconesia chlorogaster, an essentially necrophagous species (Bonatto 1996), was collected only in winter, as also observed by Moura et al. (1997).

The Sarcophagidae Peckia (Pattonella) resona is very common in carcass and had been collected by several

Table I. Insects of forensic importance collected in carcass.

\begin{tabular}{|c|c|c|c|}
\hline \multirow[t]{11}{*}{ Diptera } & Calliphoridae & $\mathrm{S}, \mathrm{A}, \mathrm{W}, \mathrm{P}$ & Lucilia eximia (Wiedmann) \\
\hline & & $\mathrm{S}, \mathrm{W}$ & Chrysomya megacephala (Fabricius) \\
\hline & & $\mathrm{S}, \mathrm{A}, \mathrm{W}, \mathrm{P}$ & Chrysomya albiceps (Wiedmann) \\
\hline & & A & Hemilucilia segmentaria (Fabricius) \\
\hline & & $\mathrm{W}$ & Hemilucilia semidiaphana (Rondani) \\
\hline & & $\mathrm{W}$ & Sarconesia chlorogaster (Wiedmann) \\
\hline & Muscidae & $\mathrm{A}, \mathrm{W}$ & Muscina stabulans (Fallén) \\
\hline & & A & Synthesiomyia nudiseta (Wulp) \\
\hline & Fanniidae & A & Fannia pusio (Wiedmann) \\
\hline & Sarcophagidae & $\mathrm{A}, \mathrm{W}$ & Peckia (Pattonella) resona (Lopes) \\
\hline & & $\mathrm{S}$ & Sarcophaga (Lyopygia) crassipalpis (Macquart) \\
\hline \multirow[t]{6}{*}{ Coleoptera } & Dermestidae & $\mathrm{S}, \mathrm{A}, \mathrm{W}$ & Dermestes maculatus (DeGeer) \\
\hline & Silphidae & $\mathrm{A}, \mathrm{W}$ & Oxyletrum discicolle (Brullé) \\
\hline & Cleridae & $\mathrm{S}, \mathrm{A}$ & Necrobia rufipes (De Geer) \\
\hline & & $\mathrm{S}, \mathrm{A}$ & Necrobia ruficolis (Fabricius) \\
\hline & Staphylinidae & $\mathrm{S}, \mathrm{A}, \mathrm{W}, \mathrm{P}$ & Gastrisus sp. \\
\hline & Histeridae & $\mathrm{S}, \mathrm{A}, \mathrm{W}, \mathrm{P}$ & Euspilotus "group"azureus sp. \\
\hline \multirow[t]{2}{*}{ Hymenoptera } & Formicidae & $\mathrm{S}, \mathrm{A}, \mathrm{W}, \mathrm{P}$ & Pheidole sp. \\
\hline & & $\mathrm{S}, \mathrm{A}, \mathrm{W}, \mathrm{P}$ & Camponotus rufipes (Fabricius) \\
\hline
\end{tabular}

S: summer; A: autumn; W: winter; P: spring. 
Table II. Periods of development according to species occurring in rabbit carcass during the year.

\begin{tabular}{|c|c|c|c|c|c|c|}
\hline \multirow[t]{2}{*}{ Taxon } & \multirow[t]{2}{*}{ Season of the year } & \multirow[t]{2}{*}{$\mathrm{N}$} & \multirow[t]{2}{*}{$\mathrm{T}\left({ }^{\circ} \mathrm{C}\right)$} & \multirow[t]{2}{*}{ I } & \multicolumn{2}{|c|}{ Development } \\
\hline & & & & & $\mathrm{X}$ & SD \\
\hline Lucilia eximia & $\mathrm{S}, \mathrm{A}, \mathrm{W}, \mathrm{P}$ & 1145 & 18.34 & L1 & 28.03 & 5.92 \\
\hline Chrysomya albiceps & $\mathrm{S}, \mathrm{A}, \mathrm{W}, \mathrm{P}$ & 379 & 17.67 & L1 & 10.26 & 2.86 \\
\hline Hemilucilia semidiaphana & $\mathrm{W}$ & 165 & 11.33 & $\mathrm{~L} 2$ & 12.41 & 2.50 \\
\hline Muscina stabulans & $\mathrm{A}, \mathrm{W}$ & 46 & 14.91 & L1 & 28.57 & 4.33 \\
\hline Fannia pusio & A & 32 & 16.00 & $\mathrm{~L} 2$ & 23 & - \\
\hline Synthesiomyia nudiseta & A & 28 & 16.23 & L1 & 27.61 & 2.08 \\
\hline Peckia (Pattonella) resona & $\mathrm{A}, \mathrm{W}$ & 22 & 14.54 & L1 & 25.53 & 2.61 \\
\hline Chrysomya megacephala & $\mathrm{S}, \mathrm{W}$ & 4 & 16.02 & $\mathrm{~L} 2$ & 11 & 0.61 \\
\hline Hemilucilia segmentaria & A & 3 & 17.60 & $\mathrm{~L} 2$ & 13.67 & 4.07 \\
\hline Sarconesia chlorogaster & W & 2 & 13.60 & L1 & 35 & - \\
\hline Sarcophaga (Lyopygia) crassipalpis & $\mathrm{S}$ & 1 & 20.70 & L1 & 24 & - \\
\hline Total & & 1827 & & & - & - \\
\hline
\end{tabular}

I: number of adults; T: mean temperature; X: mean; I: Instar; SD: standard deviation; S: summer; A: autumn; W: winter; P: spring; L1: first instar; L2: second instar.

researchers in Brazil (Moura et al. 1997; Monteiro-Filho \& Peneireiro 1987). The species was collected in autumn and winter and its larvae, as well as larvae of Calliphoridae were in found in large numbers and in no competition. The synchronic carcass exploration by larvae of Sarcophagidae and Calliphoridae does not necessarily result in competition because each of these families uses the carcass in a different way. The Sarcophagidae are ovoviviparous and deposit their larvae on the carcass, thus feeding themselves immediately. The Caliphoridae, on the contrary, deposit their eggs. The two families also differ in development period (Denno \& Cothran 1975).

Muscina stabulans and $S$. nudiseta grow on the carcass in large numbers and in specific periods. The first occurred only in autumn and winter, and the second only in winter. Muscina stabulans had collected on carcass in Brazil by Freire (1923), and therefore it still had not been characterized as being of forensic importance, but in Buenos Aires, M. stabulans occurs on carcasses is considered of forensic importance in Argentina (Centeno et al. 2002). S. nudiseta has already been collected in Rio de Janeiro, Brazil, from human corpses (Oliveira-Costa et al. 2001). Fannia pusio occurred only in autumn and was collected in Campinas (Carvalho \& Linhares 2001), in all seasons except in autumn.

Among the Coleoptera species, D. maculatus is very common in the necrophagous fauna (Sousa \& Linhares 1997; Kulshrestha \& Sapathy 2001). Authors disagree on the arrival time of the Dermestidae on carcasses. For Greenberger \& Wells (1998), they reach the cadaver approximately 30 days after death. Early and Goff (1986) collected adults three or four days after death. In our study, the species appeared seven to 10 days after death. Oxyletrum discicolle was collected from the decaying stage on and differing in seasonality. In Curitiba, Oxyletrum discicolle occurred in all seasons (Moura et al. 1997), differently from observations in the Pelotas region.

Necrobia rufipes and $N$. ruficolis are very common on carcasses; the first is used for PMI estimation (Sousa \& Linhares 1997; Kulshrestha \& Sapathy 2001). Souza and Linhares (1997) collected adult and immature individuals, and in our study, only adults were collected. The other species have the trophic role as larva predators, which makes possible the occurrence of Euspilotus "group" azureus sp. in basically all decomposition stages and in all seasons. These findings are supported by Mise et al. (2007) was collected the genus throughout the year, beginning at the bloated stage. Our data are similar, except for the autumn and spring, when adults were found from the fresh stage.

The species of Formicidae collected in our study were also reported in most studies conducted in Brazil, being considered omnivores (Monteiro-Filho \& Peneireiro 1987; Catts \& Haskell 1991; Moura et al. 1997). In spite of these considerations, the participation of Formicidae species is much more important in tropical regions (Conarby 1974). We observed that they can predate eggs, larvae, and pupae of Diptera, thus acting as a population regulation agent for the fly species population. Besides the trophic role of the members of this family in carcasses, the Formicidae are also important because they leave special marks on the carcass and can also cause lesions due to the action of formic acid. These marks and lesions can mislead an expert ass being death marks (Keh 1985).

Acknowledgments. Special thanks for Drs. José Albertino Rafael (Instituto Nacional de Pesquisas da Amazônia) and Janyra Oliveira da Costa (Secretaria de Segurança do Rio de Janeiro) for the critical reading, and Milton Amado (Universidade Federal de Pelotas) for yielding the rabbits for the experiment, and Paulo Bretanha Ribeiro (Universidade Federal de Pelotas) for the loan of the Laboratory of Biology of Insects for rearing of the immatures. To biologist Rodrigo Rickes Azevedo for the help in the identifications of the Calliphoridae. To Msc. Lisiane Dilli Wendt (Universidade Federal do Paraná) for the help in the identifications of the Fanniidae and Msc. Kleber Makoto Mise (Universidade Federal do Paraná) for the help in the identifications of the Coleoptera

\section{REFERENCES}

Bharti, M. \& D. Singh. 2003. Insect faunal succession on decaying rabbit carcasses in Punjab, Índia. Journal of Forensic Science 48: $1133-1143$. 
Bonatto, S. R. 1996. Ciclo de vida de Sarconesia chlorogaster (Wiedmann) (Diptera, Calliphoridae, Toxotarsine), criada sob condições de laboratório em dieta artificial. Revista Brasileira de Zoologia 13: 685-706.

Campobasso, C. P.; G. Di Vella \& F. Introna. 2001. Factors affecting decomposition and Diptera colonization. Forensic Science International 120: 18-27.

Carvalho, L. M. L. \& A. X. Linhares. 2001. Seasonality of insects succession and pig carcass decomposition in a natural forest área in southearstern Brazil. Journal of Forensic Science 46: 604608.

Carvalho, L. M. L.; P. J. Thyssen; M. L Goff \& A. X. Linhares. 2004. Observations on the succesion patterns of necrophagous insects on a pig carcass in a urban área of southearstern Brazil. Aggrawals Internet Journal of Forensic Medicine and Toxicology 5: 33-39.

Catts, E. P. \& N. H. Haskell. 1991. Entomological and Death: A procedual guide. Joyce's Printshop, Clemsom, 182 p, 1991.

Centeno, N.; M. Maldonado \& A. Oliva. 2002. Seasonal of arthropods occuring on sheltered na unsheltered pig carcass in Buenos Aires province (Argentina). Forensic Science International 126: 6370.

Conarby, W. B. 1974. Carrion reduction by animals in constrating tropical habitats. Biotropica 6: 51-63.

Denno, R. \& W. R. Cothran. 1975. Niche relationships of a gulid of necrophagous flies. Annals of the Entomological Society of America 68: 741-754.

Early, M. \& M. L. Goff . 1986. Arthropod succession patterns in exposed carrion on the island of O'ahu, Hawaii Islands, USA. Journal of Medical Entomology 23: 520-831.

Freire, O. 1923. Fauna cadavérica brasileira. Revista Medica 3: 1540.

Goff, M. L.; A. L. Omori \& K. Gunatilake. 1988. Estimation of postmortem interval by arthropod succession: three case studies from the Hawaiian Islands (U.S.A.). American of Journal Forensic Medical and Pathology 9: 220-225.

Gomes, L. E. \& C. J. Von-Zuben. 2004. Dispersão larval radial pósalimentar em Lucilia cuprina (Diptera: Calliphoridae): Profundidade, peso e distância de enterramento para pupação. Iheringia, Série Zoologia 94: 135-138.

Greenberg, B. \& J. D. Wells. 1998. Forensic use of Megaselia abdita and $M$. scalaris (Phoridae: Diptera): case studies, development ratyes, and eggs structure. Journal of Medical Entomology 35: 205-209.

Keh, B. 1985. Scope and applications of forensic entomology. Annual Review Entomology 30: 137-154.

Kulshrestha, P. \& D. K. Sapathy. 2001. Use of beetles in forensic entomology. Forensic Science International 120: 15-17.
Mise, K. M.; L. M. Almeida \& M. O. Moura. 2007. Levantamento da fauna de Coleoptera que habita a carcaça de Sus scrofa L., em Curitiba, Paraná. Revista Brasileira de Entomologia 51: 358 368.

Monteiro-Filho, E. L. A. \& J. L. Peneireiro. 1987. Estudo da decomposição e sucessão sobre uma carcaça animal numa área do estado de São Paulo, Brasil. Revista Brasileira de Biologia 47 289-295.

Moura, M. O.; C. J. B. Carvalho \& E. L. A. Monteiro-Filho. 1997. A preleminary analysis of insects of médico-legal importance in Curitiba, State of Paraná. Memórias do Instituto Oswaldo Cruz 92: $269-274$.

Moura, M. O. 2004. Variação espacial como promotor da coexistência em comunidades de insetos necrófagos. Revista Brasileira de Zoologia 21: 409-419.

Micozzi, M. S. 1986. Experimental study of post mortem change under field conditions: Effects of freezing thawning and mechanical injury. Journal of Forensic Science 31: 953-961.

Oliveira-Costa, J.; C. A. Melo-Patiu \& S. M. Lopes. 2001. Dipteros muscoideos associados com cadáveres humanos no local da morte, no estado do Rio de Janeiro, Brasil. Boletim do Museu Nacional, Série Zoologia 470: $1-10$.

Oliveira-Costa, J. 2008. Entomologia Forense: Quando os insetos são vestígios. Editora Millenium, Campinas, $2^{\circ}$ ed., $420 \mathrm{p}$.

Oliveira-Costa, J. \& C. A. Mello-Pattiu. 2004. Application of forensic entomology to estimate of the postmortem interval (PMI) in homicidae investigations by Rio de Janeiro Police Departament in Brazil. Aggrawals Internet Journal of Forensic Medicine and Toxicology 5: 40-44.

Richards, E. N. \& M. L. Goff. 1997. Arthropod succession on exposed carrion in three contrsting tropical habitats on Hawaii Island, Hawaii. Journal of Medical Entomology 34: 328-339.

Rodriguez, W. C \& W. M. Bass. 1983. Insect activity and its relationships to decay rates of human cadavers in East Tennessee. Journal of Forensic Science 28: 423-432.

Salviano, R. J. B.; R. P. Mello; R. F. S. Beck \& A. Ferreira. 1996. Calliphoridae (Diptera) associated with human corpses in Rio de Janeiro, Brazil. Entomologia y Vectores 3: 145-146.

Souza, A. M \& A. X. Linhares. 1997. Diptera and Coleoptera of potential forencic importance in southeastern Brazil: Relative abundance and seasonality. Medical and Veterinary Entomology 11: $8-12$.

Tantawi, T. L.; E. M. El-Kady; B. Greenberg \& H. A. El-Ghaffar. 1996. Arthropod succession on exposed rabbit carrion in Alexandria, Egypt. Journal of Medical Entomology 33: 566-580.

Weigelt, J. 1989. Recent vertebrate carcasses and their paleobiological implications. University Chicago Press. Chicago. 204 p. 